\title{
An Alternative Approach for Designing and Teaching Communication Skills to University of Technology Students
}

\author{
Ernest A. Pineteh ${ }^{1}$ \\ ${ }^{1}$ Faculty of Informatics and Design, Cape Peninsula University of Technology, Cape Town, South Africa \\ Correspondence: Ernest A. Pineteh, Faculty of Informatics and Design, Cape Peninsula University of Technology, \\ Cape Town, South Africa. E-mail: pinetehe@cput.ac.za or ernie.angu@gmail.com \\ Received: January 27, 2014 \\ doi:10.5430/ijhe.v3n2p52 \\ Accepted: March 6, 2014 \\ Online Published: April 15, 2014 \\ URL: http://dx.doi.org/10.5430/ijhe.v3n2p52
}

\begin{abstract}
This article examines the contents and teaching strategies of communication skills courses at a South African higher institution: Cape Peninsula University of Technology (CPUT). It seeks to understand why the courses have not been very responsive to increasing academic and professional challenges undergraduate students' experience at this university. Also, it proposes alternative contents and methods of teaching that can ensure that these courses remain relevant to the diversity of vocational diploma programmes offered by the university. The article is written against the backdrop of conceptions of 'unpreparedness' and 'disadvantage' repeatedly used by academics of this institution to justify the poor academic performance of students.

The article draws on data gleaned from sustained one-on-one interviews with fifteen students and four communication skills lecturers as well as on course reflections with $1^{\text {st }}$ year students collected during one academic year. This empirical data revealed that Communication courses provide a unique space for the development of generic cognitive skills which are critical for academic development and which can put graduates at a competitive advantage in the workplace. However it argues that for these courses to provide students with lifelong academic and professional skills, existing curricula and teaching approaches should be revised. This is because the current delivery methods are seemingly very pedantic, less stimulating and do not promote higher-order thinking in students. This piece therefore recommends a model, which focuses on the development of metacognitive skills such as critical thinking, creative and innovative thinking as well as problem solving.
\end{abstract}

Keywords: Cape Peninsula University of Technology, Curriculum model, Communication, Teaching and learning, South Africa

\section{Introduction}

The transformation process in a South Africa university of technology such as CPUT is supposed to concentrate not only on addressing student/staff racial and/or gender imbalances but also on redesigning curriculum documents to address the challenges associated with undergraduate students' access to academic discourse (Boughey, 2002 \& 2005; Jacobs, 2007). This entails the inclusion of courses such as Language and Communication, Academic Literacy and Business Communication in mainstream curricula. It also means fashioning the courses to transform new university entrants and reshape their understanding of ways in which knowledge is constructed and disseminated in higher education (Pineteh, 2010; Boughey, 2005; Morrow, 1994). However, there seems to be a noticeable mismatch between the contents, teaching strategies and the responsiveness of many of these courses to the increasing academic hurdles of CPUT's diploma students. This article attempts to examine existing communication skills courses in the Faculty of Informatics and Design. It seeks to understand why the courses have not been responsive to the learning challenges of students in this faculty. It also intends to propose an alternative approach for designing and teaching the courses.

The article is written against the backdrop of a myriad of misconceptions about CPUT students' problems and the varied ways to address these problems. It is also framed around increasing challenges of communication skills lecturers and deafening outcry about students' lack of cognitive abilities to engage vigorously with discipline-related academic texts (Fernstein \&Reda, 2011; Jacobs, 2007; Boughey, 2005). The article is grounded in a qualitative approach in that it draws on empirical data gleaned from sustained one-on-one interviews with fifteen students and four communication skills lecturers in 2012. It is also based on course reflections with $1^{\text {st }}$ year students and on other 
intellectual conversations with content experts and Communication lecturers. The interviews, reflections and conversations focused on the different meanings of communication skills courses and the implications for teaching and learning. In response to the voices from the data, this article proposes a theoretical and practical model that can enhance the academic and professional development of students in this faculty.

\section{Teaching and Learning in Higher Education: A South African Perspective}

Today, the scholarship of teaching and learning in higher education is informed by theoretical conceptions such as academic literacies, social constructivism, multiliteracies and new literacy studies. These conceptions have continually shaped the way educators in higher education design curricula and impart knowledge. They have also informed the formulation of educational policies and the multiple ways people learn (Englert et al, 1994; Gee \& Green, 1998; Rogers et al, 2005). For example, proponents of academic literacies such as Brian Street and Mary Lea have challenged current literacy practices in universities. Their three-tier approach to student writing in higher education (skills acquisitions, academic socialization and academic literacies) provides a prism through which to critique teaching and learning in the context of South African universities of technology. For example, a student becomes literate in a discipline-specific discourse through acculturation and by developing a unique individual identity. This means that higher education is expected to "engage students in a transformational process by encouraging critical reflection on their learning and actions" (D'Andrea \& Gosling 2005: 2). CPUT like other institutions of higher learning should be a discursive space for lecturers to socialize new students into the university environment and sculpt them into socially conscious citizens. Any university experience should therefore be transformative and enlightening, shaping students into critical and innovative thinkers as well as problem solvers, through the application of knowledge across different contexts (Kress, 1996; Street, 2004; Shore, 2010). Here, educators and learners are required to embed the process of teaching and learning within a context and to reflect on varied experiences and bring them to bear on the construction of knowledge. It also means teaching should be an interactive intellectual process whereby both educators and learners negotiate meaning through the interpretation and transfer of knowledge from different spaces (McCarthey, 1994; Winkelmann, 1995; Gee \& Green, 1998).

In post-apartheid South Africa, teaching and learning has been refocused to promote a political agenda which claims to redress the ills of the apartheid era. This agenda seeks to eradicate the infamous apartheid educational model Bantu Education and to foster an equitable educational system which is responsive to the needs of the new South Africa (Jansen, 1998; Waghid, 2002; Ensor, 2004; Badat, 2009 \& 2010). This has resulted in the irruption of different curriculum policies, educational reform and several academic Green Papers aimed at restructuring schools and universities as well as fostering the social changes promised by the new political dispensation. For example, the implementation of outcomes-based education (OBE) curriculum in 2005 and the inception of the National Qualification Framework (NQF) as well as the Higher Education Qualification Framework (HEQF) were intended to enhance the quality of education and address the imbalances in South African schools and universities (Jansen, 1998). The NQF was mandated "to steer South Africa along a high skills, high growth path of economic development [which] would lay the foundation stones of a new democracy society" (Ensor 2004: 341). And OBE was intended to forge a teaching and learning approach which privileges outcomes rather that content and process (Jansen, 1998; Ensor, 2004). These policies sought to promote diversity, multilingualism, non-racialism and non-sexism in South African universities. In addition, they intended to drive "requisite research" and contribute towards "a technologically-oriented economy (Badat 2009 \& 2010: 6). Unfortunately, the educational challenges in South Africa have very complex contours and many of these policies have been counter-productive.

Almost two decades into democracy, South Africa is still grappling with racial discrimination, gender inequality and ethnic divides, particularly in the higher education sector. Here, teaching and learning is not only about imparting knowledge but also about addressing uncharacteristic social and political challenges, stemming from the racial, multicultural and gender imbalances of the institutions (Badat, 2009 \& 2010). Today, South African universities are "increasingly being challenged in terms of their responsiveness and relevance to societal problems" (Waghid 2002: 457). This responsiveness to societal problems involves promoting equity in higher education and contributing towards deracialising the new South Africa as well as preparing students to face the challenges of global markets. For this to happen, the government seeks to increase access to higher education by dismantling the white hegemony and desecrating the elitist status of universities such as Cape Town, Witwatersrand, Stellenbosch and so on (Jansen, 1998; Waghid 2002; Badat, 2009 \& 2010). Increased access to higher education implies that these erstwhile elite universities now have to deal with previously disadvantaged and under-prepared students with inadequate basic communication and other high order skills required to cope in higher education. Because South African high schools especially in impoverished communities do not adequately prepare learners for the transition to higher education, universities are therefore burdened with the responsibility to address the myriads of socioeconomic problems that 
they bring with them to universities. So, although CPUT's throughput rates have increased, many of its graduates enter local markets or proceed to postgraduate studies without a worldview and adequate lifelong skills which can place them at competitive advantage (Pineteh, 2014; Young \& Gamble, 2006).

To ensure that higher education is truly a transformative experience to South Africans, the development of critical soft skills has occupied center stage. This has encouraged the inclusion of academic and professional development courses such as Business Communication, Academic Literacy, and Language for Business Students in mainstream curricula especially in universities of technology. These courses are intended to increase epistemological access and to ensure that knowledge is used as a vehicle of social change or as a prism for constructing individual identities in a global context (Gizir \& Simik, 2005, Badat, 2009 \& 2010; Shore, 2010). This suggests that students and academics should use a repertoire of communication skills such as nonverbal codes, semiotics systems and myriads text forms to construct social relations and give meaning to their lives as key university stakeholders (Fairclough, 1993; Kress, 1996; Gee and Green 1998). Moreover, the workplace also engenders the interplay of different communicative skills for operating both individual and team projects as well as fostering organisational identity. To this end, the courses are expected to find expression within the contention that effective communication is "the process through which social actions and interactions become constructed and reconstructed into an organizational reality" (Gizir \& Simsek 2005: 200).

\section{The Teaching of Communication at CPUT}

The inclusion of Academic Literacy, Language and Communication courses in CPUT's mainstream programmes is invariably a move to the right direction. However, the design and teaching of these courses are seemingly failing to address the problems that South African students bring to the universities. Evidence from student writings and other array of communication activities suggest that these courses have also been affected by the new vision of modern universities (Shore, 2010). Arguably, they have the potential to emancipate, empower and socialise students into discipline-specific discourses but lecturers have failed to use this space to stimulate meaningful teaching and learning. Instead, they and their like-minded colleagues in other courses are contributing to produce graduates who cannot function effectively in the South African marketplace.

In this context, the failure to drive meaningful teaching and learning has been attributed to the course contents and lecturers' teaching approaches. For students, the contents are not stimulating enough and do not provide space for the development of high-order thinking skills. Consequently, many students do not see the critical role that these courses play in their academic and professional development especially in a university of technology like CPUT. In a way, this justifies the unprecedented poor rate of attendance, low pass rates and the incessant disruptive patterns during Communication lectures (Pineteh, 2012). Despite the critical role that CPUT's Communication courses are meant to play, they are still categorised as adjunct courses by South African Department of Higher Education's funding model: Classification of Educational Subject Matter (CESM). This model classifies universities of technology mainstream and academic development courses such as Communication in different funding streams. This means that although Communication would attract the same subsidies as Sociology and Linguistics in comprehensive universities, it would attract far less in a university of technology (Badat, 2009 \& 2010). Because modern universities tend to prioritise courses that generate more subsidies, the design and delivery of the so-called "adjunct" courses especially in South African universities of technology have tended to suffer from lack of adequate human and material resources as well as contact hours (Ng'ambi \& Johnston, 2006; Shore, 2010; Pineteh 2012).

Mindful of these challenges, lecturers need to think imaginatively in order to transform the teaching of Communication into an invigorating and memorable experience for both the lecturer and the students (Thomas and De Villiers n.d.). At CPUT, this does not happen because of the pressure to cover a substantial amount of communication concepts and administer an equally substantial amount of assessments within one academic year. Because of insufficient contact hours, lecturers tend to pay more attention to work-related or vocational skills such as business correspondence, teamwork, time management and conflict management, neglecting other essential cognitive concepts such as critical thinking, problem solving, creativity, language and academic literacy (Pineteh, 2012). To minimise the risk of student failure and also promote the development of the same work-related skills, focusing on vocational skills is not a most viable strategy because students' lack of proper communication skills is a direct consequence of their complex linguistic, schooling backgrounds and literacy experiences (Jansen, 1998; $\mathrm{Ng}$ 'ambi \& Johnston, 2006). For me, the single most effective way of addressing this problem is the development of cognitive skills and "academic literacy practices - reading and writing within disciplines — [which]constitute central processes through which students learn new subjects and develop their knowledge about new areas of study" (Lea \& Street 1998: 157). 


\section{Methods of data collection}

This article examines ways in which communication skills courses are designed and taught at CPUT as well as the implications for the academic development of students. It draws on qualitative data gleaned from several professional reflections, interactions and reflective exercises with students and colleagues. In addition to reflections and interactions, unstructured interviews and informal conversations with Communication lecturers as well as the Language Coordinator of the Faculty of Informatics and Design also provided rich empirical data. To collect the data, participants were interviewed and approximately two hundred first year students in the IT department were invited to reflect on their learning experiences in these courses. The interviews, reflections and conversations focused on the role of Communication at CPUT, the challenges faced by Communication lecturers and students as well as the contents and teaching strategies. The questions were therefore framed around several issues including the usefulness of communication courses in a university of technology (UoT); lecturers and student perceptions about the courses as well as the way they are designed and taught. This triangulation of data techniques addressed the issue of trustworthiness commonly associated with the validity of qualitative data (Henning et al, 2005 \& Denzin \& Lincoln, 2002). Additionally, it provided a discursive space to appreciate discrepant views about Communication and how they shape the scholarship of teaching and learning in this context.

The analysis and discussion in this article were guided by the objectives of the project and a thematic content analysis approach was used to unlock the empirical data. Here, key themes related to the objectives were colour-coded and were used as the main entry points for analysis and discussions. The interpretation of data focused on the subjective meanings of Communication as well as the different expectations that students and lecturers bring to the courses. It also concentrated on the proposed suggestions for improving the course contents and delivery of the courses.

\section{Data analysis and discussion of findings}

Although CPUT academics are aware of the inadequacy of academic skills of their students, they still receive communication courses with skepticism and disdain. Many CPUT academics are still disingenuous about the role that these courses play in developing lifelong cognitive skills (Pineteh, 2010). But given that South African high schools have failed dismally in their mandate to prepare learners for higher education, the relevance of these courses can not be overemphasised. To foreground the courses' position in the academic and professional development of students, this article starts with an analysis of the discrepant narratives about the subjects and ultimately interrogates the implications for teaching and learning.

\subsection{Perceptions and misconceptions about communication}

For the three years that I have lectured Communication at CPUT, one of the puzzles that many of my colleagues have not managed to solve, is the role of Communication in a university of technology like CPUT. The course seems to lend itself to different interpretations from both lecturers and students, especially in the Information Technology department (IT), where I teach currently. This has had visible implications for the teaching and learning of the course. For example:

Some lecturers and students at CPUT do not understand why Communication should be included in the university curricula. For them, Communication is an extended version of English language and students did English at high school level and therefore it should not be taught at a university. For me, Communication is not English but the role of English in the teaching of Communication cannot be ignored... (Lecturer response)

Some Communication lecturers are often uncertain about the dissimilarity between English Language and Communication. The tendency to misrepresent Communication as English language is not uncommon amongst CPUT students. For many students, CPUT is not a place to study English but to acquire science, engineering and technology skills. For them, the course is supposed to ground students in the syntax of English instead of the "deep rules of [academic] culture" (Ballard \& Clanchy 1998:8). As such, students ineptitude in unlocking academic discourse is directly associated with "their status as speakers of English as an additional language" (Boughey 2002:295). By contrast, designing Communication around the exclusive grammar of English Language makes it difficult for students to understand its relevance to their academic development in a specialised discipline. Therefore, they tend to be dispassionate about the course because they imagine it as an add-on instead of an enabler.

The idea of a university of technology especially in the context of South Africa is still in a state of flux. Students come to these universities with different expectations and beliefs. They privilege CPUT because of its seemingly practical approach to teaching and learning and because it provides an opportunity to acquire essential technical 
skills for the industry. Therefore, the inclusion of courses like Communication in core curricula goes against the imaginations that students bring to this university.

I am an IT students and really do not see why I should spend time studying how to communicate. Besides, I can communicate well and most of the things that lecturers teach us are things that are easy. I can do them independently especially since most of these things are on the internet. For example, they teach us how to compile a CV [sic]. If I want one, I can always download the correct format from the internet (Student response)

This response points sharply to the focus of many communication skills courses. As an IT student, their perception of Communication is premised on the assumption that "technical people can get away with limited human contact" (Evans et al 2004: XVIII). However, "the success of systems development and IT projects depends on effective communication between users and developers" (Wynekoop \& Walz 1999: 210). Also, in the ever-changing global market of the $21^{\text {st }}$ century, the IT industry like any other industry needs "young people with minds of their own, who can present orally or in writing their views on particular proposals or development" (Kelly 1996: 8).

Furthermore, erstwhile Technikons (Technical colleges) like CPUT are still grappling with realigning "traditionally defined pedagogical variables with newly implemented, proficiency-oriented instructional outcomes" (Grove 1999: 817). Here, the position of Communication is still obfuscating especially to colleagues who have been with the institution for several years and have been caught in this unfamiliar transition to a university of technology. Unable to understand the precise role of Communication or perhaps simply being disingenuous, they have tended to embrace the course with pessimism and/or mixed feelings.

Generally the perceptions about communication especially in my department are negative. Although many lecturers think it is important, they cannot align it with professional bodies that our students are likely to service when they graduate. Clearly these lecturers are ignorant about the role of Communication in South African universities. Also, students have this false sense of confidence and care-free attitude towards Communication- they think it is a very easy course and they do not treat it in the same way they treat their main courses... (Lecturer response)

...I know the course is important but this is a university of technology, so we should be focusing on preparing these students with the technical skills that they will need in the industry. I don't see how teaching these students how to write academic essays and read different texts can help them... (Lecturer response)

Although CPUT students often relegate the course to second level, the quality of student assessments and intellectual interactions shows that they are still unable to "respond appropriately and sensitively in various professional and [academic] contexts" (Reif-Lehrer 1992: 212). In simple terms, many of them cannot read and write competently-they cannot "express themselves verbally and non-verbally in social situations" (Langsberg \& Nel 2005: 132).

\subsection{Course content and teaching strategies}

Although the tendency is always for the Communication lecturers to blame other colleagues and students, they have also contributed in devaluing the course. University courses should be designed to influence students' worldviews and the teaching strategies should be a life changing experience to students. Traditionally, lecturers have always been role models in our societies and despite the endless challenges plaguing the scholarship of teaching, they have always remained "the primary method of instruction in higher education" (Schwebel \& Schwebel 2002: 88). Their teaching approaches can shift students' perceptions about a course. In contrast, the following empirical evidence paints a blurred portrait of Communication lecturers:

One of the reasons why students and lecturers at CPUT seem not to understand the role of Communication is sometimes because of the topics covered in the subject and the teaching strategies. The course guides seem to focus too much on mechanical or discipline-specific issues. These guides seem to provide limited space for boarder cognitive skills and often do not expose students to the challenges of learning in a university. (Lecturer response)

In principle, students attend lectures because of the contribution that a course can offer to their learning experience and also because of the lecturer. But the excerpt above suggests that Communication courses have failed "to enhance the learning process beyond mere rote learning" (Schwebel \& Schwebel 2002: 88). The focus on "mechanical or discipline specific issues" suggests that the courses are responsive to the needs of particular disciplines but actually this approach devalues them, creating the impression in the minds of students that they less challenging than their 
major subjects (Kreber, 2003; Pineteh, 2010). Yet student performance in communication courses at CPUT has been very dismally low over the years. Perhaps one way to improve pass rates is for lecturers to "make teaching [and learning experience] count" through meaningful collaborative and social constructivist learning (Kreber 2003: 94).

Similar sentiments are echoed in the following quotes from a discussion with a Communication lecturer and from a student's reflection.

The way the course is designed in this university can also be blamed for the perceptions that I just mentioned. Universities are influenced by the demands of the industry. Often the support subjects like Communication tend to pay minimal interest in critical thinking and analytical skills especially at undergraduate level. Also, the lecturers do not have the right qualification to teach Communication, so they focus on topics that are easy (Lecturer response)

The course can help us a lot but the way it is taught also poses a problem with learning. For example, most of the topics that we cover are not very challenging and cannot really help us to perform well here. Many of the topics are important for the workplace but they are things that we can handle on our own-like CV, writing business letter and/or letters of application (Student response).

The misconception that Communication courses are relatively easy is untenable because in universities of technology such as CPUT, these courses produce some of the worst results. The students lack critical soft skills that can help them to engage with complex texts and projects (Thomas \& De Villier, nd; Pineteh, 2010). The mediocre student performance can also be the result of the course contents and the less invigorating teaching approaches. This undermines the value proposition that teaching should be student-centred and should speak to the diversity of CPUT students and course contents should introduce students to concepts that can imbue them with "higher-order cognitive skills" (Li, Long \& Simpson 1999: 44).

\subsection{Problems confronted by lecturers and students}

The misconceptions about Communication and the negativities from colleagues as well as the teaching strategies employed by Communication lecturers only partially describe the situation at CPUT. The failure of these courses to adequately address the soft skills deficiencies that students bring to the university can also be blamed on the university's immediate interests and the "absence of any systematic effort to understand itself, at least from an educational point of view" (Barnett 1990: 3). The university is constantly haunted by the oppositional conceptionsquality education and high throughputs rates. Although quality is the buzzword in the university's mission and vision statements, this institution's fixation with increasing the throughput rates sometimes undermines the very essence of quality education.

...There is too much emphasis on throughput rate rather that academic development. This seriously affects teaching and assessments. When we focus too much on pass rates, it affects the quality of the tuition. Poor attendance and lack of interest in Communication is still a challenge to us. Also we are still receiving negative feedback from the industry. Furthermore, the cognitive skills of our students are too weak and we cannot address this problem during the hours allocated for Communication... (Lecturer response)

...We are always under a lot of pressure to produce results but we are not provided with the resources. At CPUT, the focus seems to be about pass rates rather than on the quality of tuition and this affects the way we teach Communication... (Lecturer response)

The emphasis on high pass rates is propelled by the fact that the "South African government funding of higher education institutions is based on student throughput, as opposed to intake numbers" (Ng'ambi \& Johnston 2006: 244). By contrast, the massification of universities today cannot guarantee an increase in pass rate. Instead it puts immeasurable pressure on the university resources (Barnett, 1990; N'gambi \& Johnston, 2006). In the case of CPUT, this is simply one edge of a sharp knife. As a university of technology, it is also mandated to produce graduates for the critical skills shortage in the new South Africa. This locates the university within the ambits of the "new vision of universities as transnational business corporations operating in a competitive global knowledge economy" (Shore 2010: 15).

\subsection{The role of communication in a university of technology}

In the mist of these confusions and contestations and given that "education is not a service for a customer but an ongoing process of transformation of the participant" (Harvey, 2002 p. 253), perhaps we need to redefine the role of 
Communication in a UoT like CPUT. Mindful of the mandate of the university and the changing vision of modern universities (Shore, 2010; D'Andrea \& Gosling, 2005), Communication courses offer a unique opportunity to improve the professional and academic lives of South African students.

...Communication underpins all subjects in a university and the world of work is about communication. So Communication is a very important course in a university of technology like CPUT because it can enhance students' academic and professional skills. It can enhance students' ability to succeed in higher education because it can introduce them to a range of skills that other courses cannot... (Lecturer's response)

The excerpt above heralds the main focus of CPUT Communication courses: the enhancement of academic and professional skills. Here, the respondent opines that the central role of Communication is to prepare students for future academic challenges and for the world of work. They are supposed to provide "useful interventions ... [and with the correct contents and teaching strategies, they can] create independent learners, and instill critical mindedness" (Ng'ambi \& Johnston 2006: 244 \& Badat, 2010).

In the following quotations, the respondents also remind us about the slew of skills that Communication courses offer CPUT students, dismissing some of the perceptions discussed above.

For me I think the role of Communication tends to be confusing here at CPUT. But I believe it is a critical course especially given the quality of students that we have. Communication is one of the few courses that help students with both professional and academic skills such as application of writing, oral presentation skills, social skills, teamwork skills, conflict management skills, academic literacy and professional writing skills... (Lecturer response)

Here, the value of Communication is premised on the notion that the "deductive grammar models... [are] inadequate for the purposes of promoting communicative competence among" students (Grove 1999: 817). For these respondents, Communication offers a suite of skills that can minimise students' risk of failure and can place them at a competitive advantage in the professional world (Pineteh, 2010). These skills are also "vital to understanding how specific disciplines differentially influence learning and development" (Li, Long \& Simpson1999: 46). But, as mentioned earlier, these courses have tended to focus more on work-related skills rather than developing students cognitively through academic literacies (Lea \&Street, 2006; Badat, 2010).

\subsection{Suggestions for improvement}

In the context of teaching and learning at CPUT, students and academics seem to agree that the institution has a clear sense of where it wants to take its students especially in terms of written communication and "oral proficiency development... but how to get there most effectively" remains a quandary (Grove 1999: 817). The following suggestions provided a platform for the ensuing proposed model:

The course should develop a common conceptual platform for students before focusing on discipline specific themes. It should put more emphasis on analytical and synthesis skills. Students should be taught how to think out of the box... (Lecturer response)

I think the course and lectures should give students the opportunity to interact more, debate issues with their peers-express our points of view [sic]. This way it might be less boring. Also the lecturers should introduce some more challenging topics that can get us thinking... (Student response)

These responses reiterate the fact that Communication courses should include concepts that can stimulate high thinking processes in students. For me, these concepts include critical thinking, creativity and innovative thinking, problem solving as well as academic literacies. The development of these skills is "vital to the professional and personal success of all students" (Li, Long \& Simpson 1999: 45).

\section{The proposed model for Communication lecturers}

The university's cohort of student is an eccentric mix with disparate socioeconomic backgrounds, learning styles and interests, exemplifying the complex educational landscape of South Africa (Pineteh, 2012). Majority of CPUT students come from under-privileged high schools without requisite resources to prepare them for higher education. Many of these students are often not psychological prepared to confront the demands and stresses that come with university studies. These challenges have visible implications for the way CPUT students socialise into university culture and also for the way they interrogate academic discourse in undergraduate assessments and postgraduate research projects. They also affect their understanding of global trends and the pressures these trends are exerting on 
the South African workplace (Ivanic et al 2007; Ensor 2004; Kress 2000; Winch \& Wells 1995). In this light, Communication courses in a university of technology like CPUT are very essential because they provide an uncharacteristic space for students to develop a cross-section of critical skills that they cannot acquire from specialised courses.

This proposed curriculum model recommends replacing misnomers such as Language and Communication, English for Public Relations and English Communication with Academic and Professional Literacies as the generic course name. The new name opens space for the development of communication contents along two interrelated trajectories. The first trajectory concentrates on developing students holistically through academic literacies, critical thinking, problem solving, innovation and creativity. The second trajectory focuses on the development of technical skills and discipline specific writing skills such as teamwork, conflict management as well as business correspondence and other cognate topics. Existing curricula already address key professional skills but they do not adequately focus on concepts that can develop students' critical thinking skills. This model recognises students' lack of a mastery of English Language as one of the challenges at CPUT and it is certainly not immune to it. However, it refocuses students' attention to understanding academic discourse, issues of epistemological access. This entails socialising new university students into the processes of knowledge construction and dissemination in higher education (Morrow 1997). Moreover it concentrates on unlocking the rules and conventions of academic ways of thinking, valuing, acting, speaking, reading and writing, overt to students using mainstream curriculum" (Boughey 2002: 306). By so doing, the courses would distance themselves from the contested deficit model which associates poor academic performance of students to lack of a mastery of the rules of English as oppose to "lack of access to covert rules of academic [and profession] discourse" (Boughey 2002: 306). Here, new university entrants would be exposed to the techniques and principles of knowledge construction and dissemination in a university right from the outset and bring the knowledge to bear on understanding discipline-specific discourses (Boughey 2002). Teaching these skills to students with weak literacy backgrounds, no social capital and who are not prepared for higher education, is indeed an arduous task. But with the right resources, adequate notional hours and well-designed curricula, significant results can be achieved.

This model is potentially useful in that it provides students with a stronger foundation which can help them to approach academic discourse and discipline specific tasks in a more heuristic way. For example, existing curricula address academic literacy simplistically as reading, listening and writing. In this model we move drastically away from literacy to literacies positioning the discussions within the context of New Literacy Studies (Lea \& Street, 1998; Kress, 2000; Street, 2004). Communication lecturers should therefore deconstruct academic reading and writing not as "a set of skills or simply a means to academic socialization" (Street 2004: 9). Instead they should recognise writing at higher education level as a literacy practice which "leads to cognitive prowess and/or political emancipation" (Luke 1991: 142). Shifting from literacy to literacies implies that reading and writing in higher institutions of learning is a social practice and/or a mode of representing social meanings, ideologies and identities (Fairclough, 1993; Van Dijk, 1993; Geisler, 1994). This means ssignments should also provide space for students to think heuristically, drawing on different personal experiences and broader sociopolitical issues. They should provide a prism through which students can negotiate individual identities as human being and bring all these experiences to bear on their discipline-specific discourse. This approach is likely to influence the way South African students imagine and reconstruct post-apartheid South Africa in a global setting. It can also help students to interpret academic texts from different perspectives and bring them to bear on their academic and professional development within specialised disciplines.

For student to understand and embrace academic literacies as social practices or as mediums for cognitive prowess and emancipation, they require critical and logical thinking skills. This model therefore consider critical thinking "as a crucial aspect of the competence [students] need to participate in a plural and democratic society" like South Africa (Dam \& Volman 2004: 360). Here, democratic transformation depends on the social consciousness of its citizenry, meaning students are supposed to be change agents with the intellectual capacity to reshape the direction of the country (Badat, 2009; 2010). For this to happen, they should be able to think and make sound judgments, take informed decisions and reason logically. It also means being intellectually autonomous but yet humble enough to engage in constructive debates with peers (Rogers et al, 2005, Badat, 2010).

Although critical thinking is a meta-cognitive skill and often very challenging to teach, the students still require more than just "high level knowledge and skills" (Ruppert 2010: 1). For CPUT students to be at a competitive edge, they should be able think critically, innovatively and creatively as well as solve problems across different spectrums. Interestingly, the vision of CPUT is to be at the core of technology and innovation in Africa. For this vision to be realised, the university curricula should address these concepts from the outset. This approach should enable students 
to approach and interrogate knowledge in a more imaginative way. Furthermore, South Africa students face problems not only at the university but also in their social environments. At the university, they are confronted by several academic projects and out of the university they encounter competing socioeconomic challenges. Their success in any academic environment and in any workplace in South Africa is also contingent on their ability to solve their social problem imaginatively. Essentially, students should be able to "harness intellectual and social capital- and to convert that into novel and appropriate things" (Serrat 2009: 1). This proposed model also encourages the introduction of innovative and creative thinking as well as problem solving concepts in the course contents. Although some mainstream programmes like IT and Engineering teach these skills, combining them with critical thinking and academic literacies in one course like Communication can produce more viable outcomes.

\section{Conclusion}

Traditionally, higher education was the "realm of objective knowledge... most effectively maintained and disseminated in institutions which are relatively autonomous" (Barnett 1990: 10). Academics and students were able to interrogate societal social and political ills without prejudice or fear of victimisation. The scholarship of teaching and learning was therefore founded on the principles of collegiality, intellectual freedom and unrestricted knowledge exchange between stakeholders. However, new societal complexities such as transnationalism, globalisation, internationalisation and Africanisation have reconfigured the idea of higher education and the principles of intellectual autonomy. Seemingly, critical enquiry has become a relic of our distant past (Shore, 2010; D' Andrea \& Gosling, 2005; Barnett, 1990) and higher institutions of learning are now subjected to drastic restructuring in order to locate themselves within the new ideology of higher education. This has resulted in the commercialisation and massification of universities, with students being repeatedly imaged as 'customers' or 'clients' in the teaching and learning process (Shore, 2010 White, 2007; Franz, 1998). To subscribe to the new ideology of higher education, universities' research, teaching and learning policies should be able respond to the aforementioned discourses namely multiculturalism, Africanisation, internationalisation and globalization. Interestingly, these discourses have become very prevalent in the narratives of modern universities (Shore, 2010; Ensor, 2004) and CPUT's attempt to address them has tended to subvert its impassioned commitment to social transformation in the new South Africa. Mindful of the vision and mission of South African universities and the implications for research, teaching and learning, the disturbing reality that new entrants at CPUT often lack the requisite "cultural and social capital to make the transition into higher education" (D'Andrea \& Gosling 2005: 102) cannot be ignored. For CPUT to achieve its objectives, academics should be morally and professionally obligated to facilitate student transition from high school to university and subsequently prepare them for local and international markets. This means communication skills courses should be able to provide students with a suite of academic and professional literacies which can shape them into critical and innovative thinkers as well as problem solvers.

\section{References}

Afful, J.B.A. (2007). Academic literacy and communicative skills in the Ghanaian university: A proposal. Nebula, 4 (3): $141-159$.

Badat, S. (2009). On differentiation and diversity. Unpublished commentary.

Badat, S. (2010). The challenges of transformation in higher education and training in South Africa. Report presented to Development Bank of Southern Africa.

Barnett, R. (1990). The idea of higher education. Buckingham: Open University Press.

Boughey, C. (2002). 'Naming' students' problems: an analysis of language-related discourses at a South African university' Teaching in Higher Education. 7 (3): 294- 307. http://dx.doi.org/10.1080/13562510220144798

Boughey, C. (2005). 'Epistemological' access to the university: an alternative perspective. South African Journal of Higher Education. 19(3): 230-242. http://dx.doi.org/10.4314/sajhe.v19i3.25516

Breier, M. (ed.). (2001). Curriculum restructuring in higher education in post-apartheid South Africa. Cape Town: Educational Policy Unit, University of Western Cape.

Chick, J.K. nd. Addressing contextual issues relevant to language teaching in South Africa: Implications for policy and practice. WPEL 8 (2): 1-16.

Cranton, P. (2002). Teaching for transformation. New Directions for Adult and Continuing Education. 93: 62-71.

Cloete, N. and Bunting, I. (2000). Higher education transformation. Assessing performance in South Africa. Performance Indicators in Higher Education 3. 
D' Andrea, V. \& Gosling, D. (2005). Improving teaching and learning in higher education. A whole institutional approach. New York: Open University Press.

Denzin, N.K \& Lincoln, Y.S. (eds.) (2002). The qualitative inquiry reader. London: Sage.

Diamond, R.M. (1989). Designing and improving courses and curricula in higher education. A systematic approach. California: Jossey-Bass Inc. Publishers.

Englert, C.S., Raphael, T.E. \& Marriage, T. V. (1994). Developing a school-based discourse for literacy learning: A principled search for understanding. Learning Disability Quarterly. $17 \quad$ (1): $2-32$. http://dx.doi.org/10.2307/1511103

Ensor, P. 2004. Contesting discourses in higher education curriculum restructuring in South Africa. Higher Education. 48 (3): 339-359. http://dx.doi.org/10.1023/B:HIGH.0000035544.96309.f1

Fairclough, N. (1993). Critical discourse analysis and the marketization of public discourse: The universities. Discourse and Society. 4 (2): 138-168. http://dx.doi.org/10.1177/0957926593004002002

Franz, R.S. 1998. Whatever you do, don't treat your students like customers. Journal of Management Education. 22 (1): 63-69. http://dx.doi.org/10.1177/105256299802200105

Gee, J. P. \& Green, J.L.1998. Discourse analysis, learning, and social practice: A methodological study. Review of Research in Education. 23:119-169.

Gersten, R. (1996). Literacy instruction for language- minority students: The transition years. The Elementary School Journal. 96 (3): 227-244. http://dx.doi.org/10.1086/461825

Gizir, S. \& Simsek, H. (2005). Communication in an academic context. Higher Education 50 (2): $197-221$. http://dx.doi.org/10.1007/s10734-004-6349-x

Grove, C. (1999). Focusing on form in the communicative classroom: An output-centered model of instruction for oral skills development. Hispania. 82 (4): 817- 829. http://dx.doi.org/10.2307/346378

Harvey, L. (2002). Evaluation for what? Teaching in Higher Education. 7 (3): $245-264$. http://dx.doi.org/10.1080/13562510220144761

Henning, E., Van Rensburg, W. \& Smit, B. (2004). Finding your way in qualitative research. Pretoria: Van Schaik Publishers.

Ivanic, R., Edwards, R., Satchwell, C. \& Smith, J. (2007). Possibilities for pedagogy in further education: Harnessing the abundance of literacy. British Educational Research Journal. 33 (5): 703-721. http://dx.doi.org/10.1080/01411920701582298

Jansen, J. (1998). Curriculum reform in South Africa: A critical analysis of outcomes-based education. Cambridge Journal of Education. 28 (3): 321-331. http://dx.doi.org/10.1080/0305764980280305

Jansen, J. \& Christie, P. (eds.) (1999). Changing curriculum: Studies on outcomes-based education in South Africa. Kenwyn: Juta \& Co, Ltd.

Kreber, C. (2003). The scholarship of teaching: A comparison of conceptions held by experts and regular academic staff. Higher Education. 46 (1): 93-121. http://dx.doi.org/10.1023/A:1024416909866

Kress, G. (1996). Internationalisation and globalisation: Rethinking a curriculum of communication. Comparative Education. 32 (2): 185-196. http://dx.doi.org/10.1080/03050069628830

Langsberg, E., Kruger, D \& Nel, N. (2005). Addressing barriers to learning: A South African perspective. Pretoria: Van Schaik Publishers.

Lea, M.R. (2004). Academic literacies: A pedagogy for course design. Studies in Higher Education. 29: $739-756$. http://dx.doi.org/10.1080/0307507042000287230

Lea, M. R. (nd.) The 'academic literacies' model: Theory and applications. Theory into Practice, 45 (4): $368-377$. http://dx.doi.org/10.1207/s15430421tip4504_11

Lea, M.R. \& Street, B. V. (1998). Student writing in higher education: An academic literacies approach. Studies in Higher Education. 23: 157-172. http://dx.doi.org/10.1080/03075079812331380364

LeCouteur, A \& Delfabbro, P.H. (2001). Repertoires of teaching and learning: A comparison of university teachers and students using Q methodology. Higher Education. $42 \quad$ (2): 205-235. http://dx.doi.org/10.1023/A:1017583516646 
Li, G., Long, S. \& Simpson, M.E. (1999). Self-perceived gains in critical thinking and communication skills. Are There Disciplinary Differences? Research in Higher Education. 40 (1): 43-60. http://dx.doi.org/10.1023/A:1018722327398

Luke, A. (1991). Literacies as social practices. English Education. 23 (3): 131-147.

McCarthey, S.J. (1994). Authors, text, and talk: The internalization of dialogue from social interaction during writing. Reading Research Quarterly. 29 (3): 200-231. http://dx.doi.org/10.2307/747871

Ng'ambi, D. \& Johnston, K. (2006). An ICT-mediated constructive approach for increasing academic support and teaching critical thinking skills. Educational Technology \& Society. 9 (3): 244-253.

Paul, R. (1981). Teaching critical thinking in the 'strong' sense: A focus on self-deception, world views, and a dialectical mode of analysis. Informal Logic. 4 (2): 2-7.

Pineteh, E. (2010). Using virtual interactions to teach communication skills to information technology Students (Paper presented at the International Conference of Education, Research and Innovation, Madrid- Spain, 2010).

Pineteh, E. (2012). Using virtual interactions to teach communication skills to information technology Students. British Journal of Educational Technolog. 43, 85-96. http://dx.doi.org/10.1111/j.1467-8535.2011.01193.x

Reif-Lehrer, L. (1992). Teaching good communication/proposal- writing skills: Overcoming one deficit of our educational system. Journal of Science Education and Technology. 43 (1): 211-219. http://dx.doi.org/10.1007/BF00701364

Rogers, R., Malancharuvil-Berkes, E., Mosley, M., Hui, D. \& Joseph, G. O. (2005). Critical discourse analysis in education: A review of the literature. Review of Educational Research. 75 (3): 365-416. http://dx.doi.org/10.3102/00346543075003365

Ruppert, S.S. (2010). Creativity, innovation and arts learning. Preparing all students for success in a global economy. Arts Education Partnership.

Schwebel, D.C. \& Schwebel, M. (2002). Teaching nonverbal communication. College Teaching. 50 (3): 88-91. http://dx.doi.org/10.1080/87567550209595883

Serrat, O. (2009). Harnessing creativity and innovation in the workplace. Knowledge Solutions. 61: 1-11

Shore, C. (2010). Beyond the multiversity: neoliberalsim and the rise of the schizophrenic university. Social Anthropology. 18 (1): 15-29. http://dx.doi.org/10.1111/j.1469-8676.2009.00094.x

Sollie, D. L. \& Scott, J. P. (1983). Teaching communication skills: A comparison of videotape feedback methods. Family Relations. 32 (4): 503-511. http://dx.doi.org/10.2307/583690

Street, B. (2004). Academic literacies and 'the new orders': The implications for research and practice in student writing in higher education. Teaching and Learning in the Social Sciences. 1(1): 9-20. http://dx.doi.org/10.1386/ltss.1.1.9/0

Thomas, T. \& De Villier, C. nd. Teaching soft skills to a diverse student population: Case studies using JAD and cooperative learning techniques. Journal of Informatics Education and Research. 3 (2): 39- 52.

Van Dijk, T. (1993). The principles of critical discourse analysis. Discourse and Society. 4 (2): 249-283. http://dx.doi.org/10.1177/0957926593004002006

Waghid, Y. (2002). Knowledge production and higher education transformation in South Africa: Towards reflexivity in university teaching research and community service. Higher Education. 43 (4): 457-488. http://dx.doi.org/10.1023/A:1015211718131

White, N.R. (2007). The customer is always right?: Student discourse about higher education in Australia. Higher Education. 54 (4): 593-604. http://dx.doi.org/10.1007/s10734-006-9012-x

Winch, C. \& Wells, P. (1995). The quality of student writing in higher education: A cause for concern? British Journal of Educational Studies. 43 (1): 75-87. http://dx.doi.org/10.2307/3121758

Winkelmann, C.L. (1995). Electronic literacy, critical pedagogy, and collaboration: A case for cyborg writing. Computers and the Humanities. 29 (6): 431-448. http://dx.doi.org/10.1007/BF01829875

Young, M. \& Gamble, J. (eds.) (2006). Knowledge. curriculum and qualifications for South African further education. Cape Town: Human Sciences Research Council. 